\title{
Analisis Penyebab Kematian Maternal Di Kabupaten Garut (Studi Epidemiologi dalam Upaya Menurunkan Kematian Maternal di Provinsi Jawa Barat)
}

\author{
Dhita Aulia Octaviani ${ }^{1}$ Farid Husin ${ }^{2}$ Firman F. Wirakusumah ${ }^{3}$ Hadi Susiarno ${ }^{4}$ Hadyana Sukandar ${ }^{5}$ Dadan $_{\text {Susandi }}{ }^{6}$ \\ ${ }^{1}$ Poltekkes Kemenkes Semarang \\ ${ }^{2-5}$ Fakultas Kedokteran Universitas Padjadjaran \\ ${ }^{6}$ RSUD Dr. Slamet Kabupaten Garut
}

Corresponding author: Dhita Aulia Octaviani

Email: dhitaaulia@poltekkes-smg.ac.id

Received : February $21^{\text {th }}, 2019$; Revised: March $18^{\text {th }}, 2019$; Accepted: April 19 $9^{\text {th }}, 2019$

\begin{abstract}
Maternal mortality is still a problem globally and especially occur in developing countries, including Indonesia. The maternal mortality rate is one indicator of the health status of a country. Garut is one part of West Java province with the count of maternal mortality case was 45 deaths in 2015. Most of the causes of maternal death is preventable, ie factors of patients, healthcare workers, facilities, and referral. Recording and reporting of maternal deaths has not to be going well yet, so that intervention can not be set to decrease maternal mortality significantly. Research carried out by sequential explanatary mixed method. The first phase, data collection and analysis is done quantitatively, followed by collection of qualitative data in the second phase which aims to strengthen the results of quantitative research. Quantitative research using cross sectional and qualitative study using in-depth interviews and focus group discussions. The study was conducted in October-November, 2016. Based on the research showed that $96 \%$ of maternal deaths occur in Garut regency are preventable maternal deaths that caused by multifactorial, a combination of healthcare workers factors, patient factors, and referral factors. Maternal deaths are also caused by the referral process has been delayed. Besides that, recording and reporting have not been able to run well, with the availability of human resources, but the existing policy has not been adequate. Patient factors such as age, parity, and birth spacing is at risk, as well as negative perceptions of mothers and families to health facilities contributed to preventable maternal deaths. Health workers factor prefer to unqualified health workers in conducting effective communication and counseling. Access, financing, and poor communication between health professionals and patients have contributed to the occurrence of resistance in the referral process.
\end{abstract}

Keyword: preventable maternal mortality, delay in referral process, recording and reporting

\section{Pendahuluan}

Kematian maternal masih menjadi salah satu permasalahan global dan terutama terjadi pada negara-negara berkembang (Ansariadi, 2014). Data WHO mengemukakan bahwa kematian maternal yang disebabkan oleh penyebab langsung, seperti komplikasi kehamilan dan persalinan secara global mengalami penurunan sebesar $44 \%$ dalam 25 tahun terakhir, yaitu menjadi 216 kematian per 100.000 kelahiran hidup pada tahun 2015 dari 385 kematian per 100.000 kelahiran hidup pada tahun 1990 (WHO, 2015).
Berdasarkan data Survei Demografi dan Kesehatan Indonesia (SDKI), AKI di Indonesia pada tahun 2012 adalah 359/100.000 kelahiran hidup. Angka ini meningkat jika dibandingkan AKI tahun 2007 yang berada pada angka 228/100.000 kelahiran hidup dan mengindikasikan bahwa target ke-5 Millennium Development Goals (MDGs) yaitu menjadikan AKI di Indonesia sebesar 102/100.000 kelahiran hidup pada tahun 2015 yang lalu tidak tercapai (Pusdatin Kemenkes RI, 2013 dan BPS, 2013)

Lima penyebab utama kematian maternal di dunia merupakan penyebab langsung, yaitu perdarahan, hipertensi dalam kehamilan (HDK), 
infeksi, partus lama/macet, dan abortus. Di Indonesia, penyebab kematian maternal masih didominasi oleh perdarahan, HDK, dan infeksi, namun proporsi ketiga penyebab kematian maternal telah berubah, di mana perdarahan dan infeksi mengalami penurunan, sedangkan HDK mengalami peningkatan. Pada tahun 2010, lebih dari $30 \%$ kematian maternal di Indonesia disebabkan oleh HDK (Kemenkes RI, 2013).

Kematian maternal diperkirakan sebesar 99\% terjadi di negara berkembang dan 37-90\% dari kematian tersebut dapat dicegah, yang artinya jika ibu mendapat pertolongan atau datang ke fasilitas kesehatan pada saat yang tepat dan langsung mendapatkan perawatan yang memadai, maka kematian tersebut dapat dihindari. Berdasarkan penelitian yang dilakukan oleh Merali, dinyatakan bahwa terdapat 42 faktor penyebab kematian maternal yang dapat dicegah, yang dikategorikan menjadi empat kategori: faktor yang berkaitan dengan petugas kesehatan menjadi faktor utama $(66,7 \%)$, faktor yang berhubungan dengan pasien $(14,3 \%)$, faktor administrasi/sarana prasarana $(11,9 \%)$, dan faktor transportasi/rujukan $(7,1 \%)$ (Merali, 2014).

Faktor yang berkaitan dengan petugas kesehatan terutama disebabkan oleh perawatan di bawah standar yang diberikan dan diperkirakan berkontribusi sebanyak 28,5\% terhadap kematian maternal; faktor pasien meliputi karakteristik pasien, seperti: usia, jarak kelahiran, paritas, pendidikan, perilaku sehat seperti kunjungan ANC dan penggunaan alat kontrasepsi; dan ketepatan dalam mengenali tanda bahaya dan mengambil keputusan; faktor sarana prasarana/administrasi lebih kepada kurangnya persediaan darah, kekurangan obat dan peralatan medis; dan faktor rujukan sangat berkaitan dengan kurangnya transportasi menuju fasilitas kesehatan yang dipengaruhi oleh wilayah tempat tinggal, letak geografis, serta akses menuju fasilitas kesehatan (Merali, 2014).

Rujukan kesehatan merupakan salah satu bagian penting dalam penyelenggaraan pelayanan kesehatan. Pelaksanaan rujukan yang tidak cepat dan tepat dapat berkontribusi terhadap terjadinya kematian maternal. Sistem rujukan mengatur dari mana dan harus kemana seseorang dengan gangguan kesehatan tertentu memeriksakan penyakitnya. Namun, di Indonesia sering terjadi ketimpangan di masyarakat di mana pemahaman masyarakat mengenai alur rujukan masih terbilang rendah sehingga sebagian dari mereka terlambat dalam menerima pelayanan kesehatan. Thaddeus dan Maine mengaitkan penyebab kematian maternal dengan Tiga Terlambat, yaitu terlambat dalam mengenali tanda bahaya dan terlambat mengambil keputusan untuk mencari pertolongan, terlambat dalam mencapai fasilitas kesehatan, dan terlambat menerima pelayanan kesehatan yang memadai setibanya di tempat rujukan (Lim, 2016 dan Pacagnella, 2012).

Pemerintah Indonesia telah melakukan berbagai upaya untuk menurunkan kematian maternal, di antaranya Gerakan Sayang Ibu, Making Pregnancy Safer, Desa Siaga, Jampersal, PONED, PONEK, dan terakhir adalah program EMAS (2012-2016) yang berfokus pada penguatan sistem rujukan yang efektif dan efisien di rumah sakit dan puskesmas, namun program-program tersebut belum mampu menurunkan kematian maternal secara signifikan (USAID, 2016).

Kasus kematian maternal juga masih menjadi permasalahan di Jawa Barat. Pada tahun 2014, kasus kematian maternal berada pada peringkat ketiga teratas di Indonesia, yaitu sebanyak 748 kasus dan mengalami peningkatan pada tahun 2015 menjadi 823 kasus. Penyebab tertinggi masih disebabkan oleh HDK (31\%), perdarahan (30\%), dan infeksi (6\%) (Dinkes Prov Jabar, 2014).

Semua kematian maternal seharusnya dicatat dan dilaporkan secara lengkap oleh sistem registrasi vital/sipil. Dari sistem yang sudah ada, belum ada yang dapat mengidentifikasi faktorfaktor yang potensial dapat dicegah. Jika faktorfaktor yang berkontribusi terhadap kematian maternal dapat diidentifikasi, seharusnya kematian maternal dapat terhindarkan. Faktor yang menyebabkan tidak tercatat/terlaporkannya kematian maternal di antaranya adalah faktor kebijakan, faktor sumber daya manusia (SDM), dan faktor biaya/honor (McCaw-Binns, 2014 dan Jentoft, 2014).

Kabupaten Garut merupakan salah satu kabupaten yang pada tahun 2014 lalu menduduki peringkat ke-6 sebagai penyumbang kasus kematian maternal tertinggi di Provinsi Jawa Barat dengan jumlah 45 kasus kematian. Berdasarkan studi pendahuluan, pada tahun 2014 masih terdapat 6 kasus kematian yang terjadi di rumah dan 7 kasus terjadi di perjalanan serta lebih dari $50 \%$ kasus terjadi di rumah sakit, yang menunjukkan bahwa proses rujukan belum berjalan dengan baik. Pada tahun 2015, dari 45 kasus kematian, 10 persalinan masih ditolong oleh paraji. Hal ini juga 
dikontribusi oleh tingkat pengetahuan ibu yang rendah, khususnya di bidang kesehatan dan permasalahan sosial ekonomi yang rata-rata memang berada pada sosial ekonomi menengah ke bawah.

Penelitian ini bertujuan untuk menganalisis faktor-faktor penyebab kematian maternal yang seharusnya dapat dicegah di Kabupaten Garut, menganalisis faktor-faktor yang menghambat proses rujukan, serta menganalisis faktor-faktor yang berkaitan dengan pencatatan dan pelaporan kematian maternal di Kabupaten Garut.

\section{Metode Penelitian}

Rancangan penelitian ini menggunakan desain penelitian sequential explanatory mixed method. Tahap pertama dilakukan secara kuantitatif menggunakan metode deskriptif pada 45 dokumen OVM (Otopsi Verbal Maternal) dan RMMP (Rekam Medis Maternal Perantara), dilanjutkan dengan tahap kualitatif dengan melakukan in depth interview dan Focus Group Discussion (FGD) pada keluarga, tenaga kesehatan, dan petugas pencatatan pelaporan kematian maternal. Penelitian ini dilakukan di Kabupaten Garut pada bulan Oktober-November 2016.

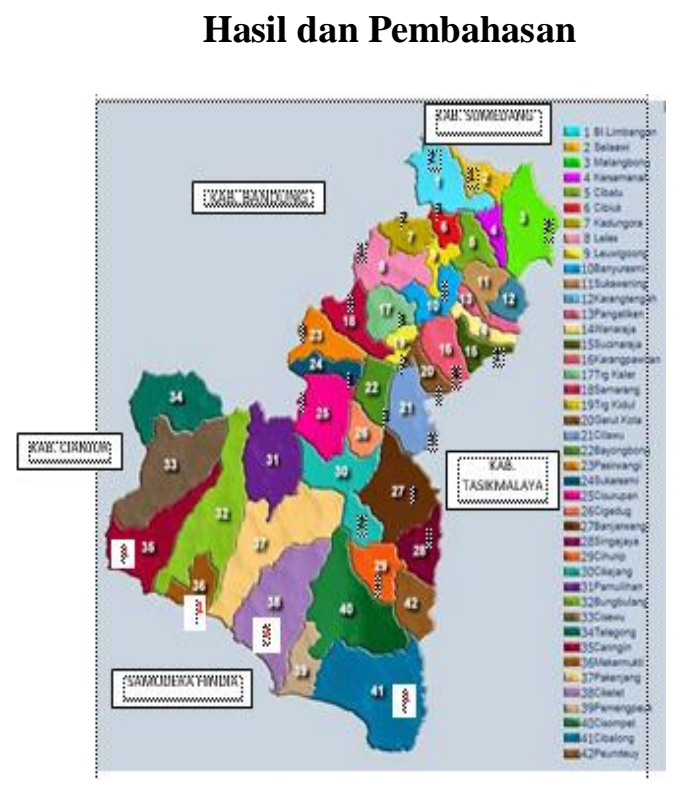

Berdasarkan peta sebaran kasus kematian maternal, dapat terlihat bahwa kematian maternal yang terjadi di Kabupaten Garut pada tahun 2015 menyebar, tidak mengelompok di suatu wilayah. Dari 42 kecamatan yang terdapat di Kabupaten
Garut, kasus kematian maternal terjadi di 26 kecamatan. Dari 26 kecamatan ini, hampir seluruhnya merupakan daerah dataran tinggi (22 kecamatan), dengan ketinggian wilayah 500-1000 mdpl, yang sebagian besar berada pada Kabupaten Garut yang berbatasan dengan Kabupaten Bandung, Kabupaten Sumedang, dan Kabupaten Tasikmalaya, sedangkan empat kecamatan lainnya merupakan dataran rendah dengan ketinggian 0500 mdpl yang terletak di Kabupaten Garut bagian selatan yaitu Kecamatan Caringin, Kecamatan Mekarmukti, Kecamatan Cikelet, dan Kecamatan Cibalong. Kecamatan Karangpawitan merupakan kecamatan di mana kasus kematian maternal paling banyak terjadi, yaitu sebesar 4 kasus. Jika dilihat secara geografis, kecamatan ini merupakan kecamatan yang masih berada di wilayah kota di mana kondisi jalan sudah baik dan tidak sulit untuk mendapatkan transportasi dari rumah menuju fasilitas kesehatan primer ataupun sekunder.

Tabel 1

Kematian Maternal Berdasarkan Karakteristik Ibu

\begin{tabular}{|c|c|c|}
\hline Variabel & Jumlah & Persentase \\
\hline & $\mathbf{n}$ & $\%$ \\
\hline \multicolumn{3}{|l|}{ Usia } \\
\hline$<20$ tahun & 4 & 8,9 \\
\hline 20-35 tahun & 28 & 62,2 \\
\hline$>35$ tahun & 13 & 28,9 \\
\hline \multicolumn{3}{|l|}{ Paritas } \\
\hline 1 & 10 & 22,2 \\
\hline $2-4$ & 20 & 44,4 \\
\hline$>4$ & 12 & 26,7 \\
\hline \multicolumn{3}{|l|}{ Jarak kelahiran } \\
\hline$\leq 2$ tahun & 4 & 8,9 \\
\hline$\geq 2-5$ tahun & 27 & 60 \\
\hline \multicolumn{3}{|l|}{ Penyakit penyerta } \\
\hline Ada & 19 & 42,2 \\
\hline Tidak ada & 26 & 57,8 \\
\hline \multicolumn{3}{|l|}{ Kunjungan ANC } \\
\hline$<4$ kali & 13 & 28,9 \\
\hline$\geq 4$ kali & 32 & 71,1 \\
\hline \multicolumn{3}{|l|}{ Pendidikan } \\
\hline SD & 23 & 51,1 \\
\hline SMP & 16 & 35,6 \\
\hline SMA & 5 & 11,1 \\
\hline Perguruan Tinggi & 1 & 2,2 \\
\hline \multicolumn{3}{|l|}{ Periode Kematian } \\
\hline Hamil & 11 & 24,4 \\
\hline Bersalin & 15 & 33,3 \\
\hline Nifas & 19 & 42,2 \\
\hline \multicolumn{3}{|l|}{ Tempat Kematian } \\
\hline Rumah & 5 & 11,1 \\
\hline
\end{tabular}




\begin{tabular}{lcc} 
Perjalanan & 5 & 11,1 \\
PONED & 1 & 2,2 \\
Rumah Sakit & 33 & 73,3 \\
\hline
\end{tabular}

Dari tabel 1 terlihat bahwa kematian maternal lebih banyak terjadi pada rentang usia reproduksi sehat (20-35 tahun), yaitu sebanyak 28 kasus $(62,2 \%)$; dari segi paritas juga lebih banyak terjadi pada rentang paritas yang aman (2-4) sebanyak 20 kasus $(44,4 \%)$ di mana 1 kasus merupakan abortus, dan 2 kasus lainnya data tidak tersedia; dilihat dari jarak kelahiran, $60 \%$ kematian maternal terjadi pada jarak kelahiran berisiko rendah (> 2 tahun); lebih dari 50\% kasus kematian maternal justru terjadi pada ibu dengan tanpa penyakit penyerta $(57,8 \%)$ dan dengan kunjungan ANC $\geq 4$ kali $(71,1 \%)$; sebesar 23 kasus merupakan ibu dengan pendidikan dasar/SD $(51,1 \%)$; periode kematian terbanyak terjadi pada masa nifas $(42,2 \%)$ dan kematian terbanyak terjadi di rumah sakit, yaitu sebanyak 33 kasus $(73,3 \%)$.

Kematian maternal di Kabupaten Garut masih didominasi akibat perdarahan yang mayoritas disebabkan karena retensio plasenta dan atonia uteri yang tidak tertangani akibat tidak tersedianya pasokan darah. Penyebab kedua diakibatkan oleh hipertensi dalam kehamilan/HDK (preeklamsi dan eklamsi), seperti yang diutarakan oleh responden:

"Ya darah....itu permasalahan kita di sana...yang kedua emang kasus-kasusnya yang lebih populer itu hipertensi dalam kehamilan, eklamsi ya..."

Kondisi yang terjadi di Kabupaten Garut ini tidak sesuai dengan literatur yang menyatakan bahwa penyebab kematian maternal tertinggi di dunia saat ini adalah HDK (preeklamsi dan eklamsi).

Tabel 2

Kematian Maternal di Kabupaten Garut Tahun 2015

\begin{tabular}{lcc}
\hline \multicolumn{1}{c}{ Kategori } & Jumlah & Persentase \\
\hline $\begin{array}{l}\text { Kematian dapat } \\
\text { dicegah }\end{array}$ & 43 & $96 \%$ \\
\hline $\begin{array}{l}\text { Kematian tidak } \\
\text { dapat dicegah }\end{array}$ & 2 & $4 \%$ \\
\hline
\end{tabular}

Dari tabel 2 dapat diketahui bahwa dari 45 kasus kematian maternal di Kabupaten Garut, 96\% merupakan kematian maternal yang seharusnya dapat dicegah. Terdapat dua kematian yang tidak dapat dicegah yang disebabkan oleh emboli air ketuban dan anemia aplastik. Hal ini didukung dengan pernyataan responden:

"Sebenernya sebagian besar dapat dicegah, pertama dari ANC, kemudian yang kedua dari persalinan juga ya harus udah nakes, dan stiker, kalo P4K nya berjalan insya Allah..."

Tabel 3

Distribusi Frekuensi Faktor-faktor Penyebab Kematian Maternal yang Dapat Dicegah di Kabupaten Garut Tahun 2015

\begin{tabular}{lcc}
\hline \multicolumn{1}{c}{ Faktor-Faktor } & Jumlah & Persentase \\
\hline $\begin{array}{l}\text { Pasien dan nakes } \\
\text { Pasien, nakes, dan } \\
\text { rujukan }\end{array}$ & 9 & $20,9 \%$ \\
$\begin{array}{l}\text { Pasien, nakes, } \\
\text { sarpras, }\end{array}$ & 3 & $23,3 \%$ \\
$\begin{array}{l}\text { dan rujukan } \\
\text { Nakes dan rujukan }\end{array}$ & 2 & $6,9 \%$ \\
Pasien dan sarpras & 2 & $4,7 \%$ \\
Pasien & 3 & $6,7 \%$ \\
Sarpras dan rujukan & 2 & $4,7 \%$ \\
Pasien, sarpras, & 2 & $4,7 \%$ \\
dan rujukan & & \\
Pasien, nakes, dan & 3 & $6,9 \%$ \\
sarpras & & \\
Nakes, sarpras, & 2 & $4,7 \%$ \\
dan rujukan & & \\
Nakes dan sarpras & 1 & $2,3 \%$ \\
Pasien dan rujukan & 2 & $4,7 \%$ \\
Nakes & 2 & $4,7 \%$ \\
Jumlah & $\mathbf{4 3}$ & $\mathbf{1 0 0 \%}$ \\
\hline
\end{tabular}

Dari tabel 3 terlihat bahwa kematian maternal yang dapat dicegah bukan berasal dari faktor tunggal, namun sebagian besar disebabkan oleh multifaktor,. Faktor pasien meliputi karakteristik pasien itu sendiri, seperti: usia, paritas, jarak kelahiran, dan adanya penyakit penyerta; faktor tenaga kesehatan lebih kepada konseling yang kurang efektif, baik itu mengenai $\mathrm{KB}$, tanda bahaya, serta persalinan yang bersih dan aman; faktor sarana prasarana berasal dari ketidaktersediaan obat, ruangan, peralatan, stok darah, dan juga SDM; dan faktor rujukan berkaitan dengan faktor keterlambatan yang disebabkan oleh letak geografis, wilayah tempat tinggal, akses menuju fasilitas kesehatan, dan pembiayaan. Jika diakumulasikan per satu faktor, faktor pasien menjadi penyebab utama kematian maternal di 
Kabupaten Garut, yaitu sebesar $85 \%$, disusul dengan faktor tenaga kesehatan sebesar 74,4\%.

Tabel 4

Faktor-faktor yang Menyebabkan Hambatan dalam Proses Rujukan

\begin{tabular}{lcc}
\hline \multicolumn{1}{c}{ Variabel } & \multicolumn{2}{c}{ Rujukan Terhambat } \\
\cline { 2 - 3 } & Jumlah & $\mathbf{\%}$ \\
\hline $\begin{array}{l}\text { Geografis tempat } \\
\text { tinggal }\end{array}$ & & \\
Dataran tinggi & $\mathbf{2 3}$ & $\mathbf{9 5 , 8}$ \\
Dataran rendah & $\mathbf{1}$ & $\mathbf{4 , 2}$ \\
Akses & & \\
- Jarak tempuh & & \\
$>5 \mathrm{~km}$ & $\mathbf{1 8}$ & $\mathbf{7 5}$ \\
$\leq 5 \mathrm{~km}$ & $\mathbf{6}$ & $\mathbf{2 5}$ \\
- Waktu tempuh & & \\
$>2$ jam & $\mathbf{5}$ & $\mathbf{2 0 , 8}$ \\
$\quad$ 2jam & $\mathbf{1 9}$ & $\mathbf{7 9 , 2}$ \\
- Transportasi & & \\
Tidak tersedia & $\mathbf{1 1}$ & $\mathbf{4 5 , 8}$ \\
$\quad$ Tersedia & $\mathbf{1 3}$ & $\mathbf{5 4 , 2}$ \\
Wilayah & & \\
tinggal & & $\mathbf{6 2 , 5}$ \\
Perdesaan & $\mathbf{1 5}$ & $\mathbf{3 7 , 5}$ \\
Perkotaan & $\mathbf{9}$ & $\mathbf{8 7 , 5}$ \\
Pembiayaan & & $\mathbf{1 2 , 5}$ \\
Mandiri & $\mathbf{2 1}$
\end{tabular}

Dari 45 kasus kematian, 24 kasus merupakan kasus rujukan yang mengalami keterlambatan. Berdasarkan tabel 4, hampir seluruh kematian maternal yang dapat dicegah terjadi pada ibu yang bermukim pada dataran tinggi $(95,8 \%)$. Hal ini disebabkan karena memang hampir seluruh wilayah di Kabupaten Garut merupakan daerah dataran tinggi dengan kondisi perbukitan dan pegunungan sehingga di beberapa tempat letak geografis memang menjadi masalah.

“... kondisi dari sini ke Polindes jauh...yang tadi pas itu, digotong pakai tandu...makanya di sini letak geografisnya yang jadi bermasalah..."

Dari 24 kematian maternal yang mengalami hambatan rujukan, 18 di antaranya merupakan wilayah yang berjarak tempuh lebih dari $5 \mathrm{~km}$, namun untuk waktu tempuh, hanya 5 dari 24 kematian maternal tersebut yang memerlukan waktu $\geq 2$ jam untuk mencapai ke fasilitas kesehatan dasar, baik bidan maupun puskesmas sehingga dapat dikatakan bahwa jarak tempuh tidak menyebabkan kematian, namun kesulitan untuk mencapai fasilitas kesehatan akibat letak geografis menyebabkan waktu tempuh menjadi lebih lama sehingga dapat mengakibatkan keterlambatan dalam proses rujukan.

"Letak geografisnya Bu...dari kalau merujuk dari Limbangan ke Garut kan butuh waktu lama itu Bu..."

Ketidaktersediaan transportasi berkontribusi terhadap 11 kematian maternal yang dapat dicegah. Jarak dan waktu tempuh serta transportasi berkaitan dengan akses dari rumah menuju fasilitas kesehatan yang sulit, yang bahkan kendaraan roda dua (sepeda motor) saja sulit untuk melewatinya.

"...ditandu neng...sampe bawah, sampai bawah di situ, baru pake motor ke puskesmasnya..."

"Puskesmas kan dari Cisarua susah transportasinya..."

"...kendaraannya sangat misalkan kalau tidak ada ambulans, kendaraan sangat minim kalau malam..."

Kematian maternal yang dapat dicegah sebagian besar terjadi pada wilayah pedesaan, yaitu sebesar $62,5 \%$. Hal ini sesuai dengan literatur yang menyatakan bahwa kematian maternal banyak terjadi di pedesaan berkaitan dengan pernikahan usia dini yang masih banyak terjadi dan rendahnya tingkat pendidikan di pedesaan.

Faktor pembiayaan pada kematian maternal yang dapat dicegah, hampir seluruhnya merupakan pembiayaan mandiri (87,5\%). Rata-rata masyarakat berpikiran bahwa kalau tidak sakit, tidak usah mengurus BPJS. Biaya untuk persalinan, bahkan untuk sekadar transportasi ambulance pun bisa dikatakan menjadi permasalahan, di mana memang sebagian besar kasus kematian maternal di Kabupaten Garut berasal dari sosial ekonomi menengah ke bawah.

“... di sini mah susah neng, memang di lingkungan seperti itu. Jadi kalau masuk rumah sakit, eh sebelum masuk rumah sakit teh baru bikin gitu..." nah sekarang kan aturannya BPJS harus satu keluarga semua, ...itu kan kalau punya anaknya 4 atau 5 tambah orangtuanya 2, meskipun 25 ribu satu orang, tapi kan kalau untuk sekaligus, duit dari mananya Ibu teh?...” (Indepth Ny S)

"Iya, kan kakak mah warung kecil-kecilan, suaminya juga dagang kecil-kecilan jadi ya mungkin nggak tahulah, nggak tahu pikirannya ke sana, mungkin dana gitu. Dana sih yang itu mah, kalau ke rumah sakit teh cuma bawa uang 100 ribu." 
“...pas sampai di sini baru bilang udah nggak ada buat biaya ambulance..." (indepth $\mathrm{Ny}$ $\mathrm{H})$

Tabel 5

Faktor-faktor Pencatatan Pelaporan Kematian Maternal

\begin{tabular}{ll}
\hline \multicolumn{1}{c}{ Faktor } & \multicolumn{1}{c}{ Keterangan } \\
\hline SDM & Ada \\
Kebijakan & Tidak Ada \\
Biaya/Honor & Tidak Ada \\
\hline
\end{tabular}

Tabel 5 menunjukkan bahwa SDM yang melakukan pencatatan dan pelaporan kematian maternal tersedia meskipun berganti-ganti, namun demikian penunjukan SDM tersebut tidak disertai dengan Surat Keputusan (SK) atau Surat Tugas, hanya penunjukan secara lisan yang dilakukan berdasarkan diskusi internal. Tidak ada honor tambahan untuk petugas yang mendapat tugas untuk melakukan pencatatan dan pelaporan kematian maternal.

"Ada yang bertanggung jawab terhadap pencatatan dan pelaporan kematian, tapi dia ya gak kepegang juga....kita kan merangkap rangkap, kalo yang sekarang merangkap sebagai bendahara pengeluaran juga..."

"Surat tugasnya tidak ada, tapi secara lisan pembagian tugas kita aja di seksi gitu"

"Nggak, nggak ada honor tambahan, sama aja kaya staf yang lain gitu..."

Pengisian data pada OVM ditemukan banyak yang tidak lengkap, terutama di bagian alur rujukan. Untuk kematian yang terjadi di RS, disebutkan kesulitan untuk meminjam rekam medisnya, sehingga terkadang apa yang ditulis di OVM hanya sampai kondisi saat merujuk.

"Kalo yang meninggal di RS kadang susah minta datanya, bertele-tele birokrasinya. Jadi kadang yang ditulis di OVM cuma sampe saat terakhir kondisi dirujuk. Udah sampai di rumah sakit kadang kita gak tau gimana-gimananya lagi. Kalo dulu sih masih bisa..."

Ditemukan pula teknik pengisian yang berbeda-beda pada lembar OVM. Dari hasil kualitatif didapatkan sudah pernah dilakukan pelatihan pengisian OVM, namun diberlakukan hanya untuk bidan koordinator, sedangkan OVM terkadang dilakukan oleh bidan desa/bidan yang menangani kasus kematian.
Di Kabupaten Garut, berdasarkan pemetaan kematian maternal, didapatkan kematian maternal menyebar, tidak mengelompok di suatu daerah. Dari 42 kecamatan yang ada di Kabupaten Garut, 26 di antaranya terdapat kematian maternal. Hampir seluruh kecamatan yang terdapat kematian merupakan daerah dataran tinggi. Seiring dengan perkembangan teknologi, untuk pencatatan dan pelaporan sudah mulai berkembang ke arah yang lebih baik dengan dibentuk grup WhatsApp yang berjudul Konsultasi Ahli, bekerja sama antara Dinas Kesehatan, RSU, dokter spesialis obstetri ginekologi, dan bidan-bidan, baik bidan puskesmas maupun bidan desa.

Kecamatan Karangpawitan merupakan kecamatan dengan kematian terbanyak dibandingkan dengan kecamatan lainnya. Jika dilihat dari geografis, kecamatan ini masih berada di sekitar wilayah kota. Kondisi jalan bagus, akses untuk menuju ke fasilitas kesehatan juga terbilang mudah, dan lokasi-lokasi yang terdapat kematian maternal pun tidak jauh dari fasilitas kesehatan. Hal ini menunjukkan bahwa semua kejadian kehamilan berisiko dan bisa terjadi tanpa terprediksi meskipun berada di lokasi yang menjangkau fasilitas kesehatan.

\section{Penyebab kematian maternal yang tidak dapat dicegah}

Berdasarkan data kuantitatif dan kualitatif yang diperoleh, dari 45 kematian maternal yang terjadi, terdapat dua kematian yang merupakan kematian maternal yang tidak dapat dicegah, yaitu dikarenakan oleh emboli air ketuban dan anemia aplastik.

\section{Penyebab kematian maternal yang dapat dicegah di Kabupaten Garut}

\section{Faktor pasien/faktor ibu}

Berdasarkan tabel 1 , kematian maternal di Kabupaten Garut sebagian besar terjadi pada rentang usia reproduktif (20-34 tahun), yaitu 28 dari 45 kasus kematian. Banyak yang merencanakan kehamilan pada rentang usia ini karena dianggap paling aman. Namun demikian, seperti kita ketahui bahwa kejadian kehamilan merupakan risiko, sehingga meskipun rentang usia ini merupakan rentang usia yang aman untuk hamil, dengan meningkatnya kejadian kehamilan, maka akan semakin meningkatkan risiko terjadinya kematian maternal. 
Selain usia, paritas dikatakan juga memengaruhi kematian maternal. Berdasarkan literatur, paritas 1 atau lebih dari 4 merupakan keadaan yang berisiko untuk terjadinya kematian maternal. Berdasarkan tabel 1, di Kabupaten Garut, kematian maternal yang dapat dicegah paling banyak terjadi pada paritas yang tidak berisiko (24) yaitu sebesar $44,4 \%$. Namun demikian, masih didapatkan paritas lebih dari 4 (grandemultipara), yaitu sebanyak 12 kasus. Paritas yang tinggi di Kabupaten Garut salah satunya dikarenakan karena program KB yang kurang disambut antusias oleh masyarakat. Permasalahan lainnya adalah belum optimalnya pelayanan KB khususnya bagi keluarga miskin, masyarakat di daerah terpencil dan daerah perbatasan akibat terbatasnya kemampuan masyarakat dan pemerintah daerah baik sarana prasarana pelayanan serta petugas medis dan penyuluh KB.

Hal ini pun dikeluhkan oleh responden yang menyatakan bahwa memang sangat sulit untuk mengajak warga ber-KB. Selain dari segi pendidikan yang rendah, kemauan masyarakat untuk bisa hidup lebih sehat dan sejahtera pun terbilang rendah. Di samping itu, penyuluh $\mathrm{KB}$ tidak menjalankan tugas sebagaimana mestinya. Penyuluhan, pemberian informasi mengenai apa itu KB, jenis, manfaat, indikasi dan kontra indikasi tidak dijelaskan secara gamblang, sehingga kebanyakan warga hanya ber-KB "ikut-ikutan". Itupun hanya terbatas pada penggunaan $\mathrm{KB}$ jenis pil dan suntik. Untuk penggunaan implan dan IUD masih sedikit, dengan alasan takut gemuk atau takut saat berhubungan akan terganggu karena harus memasukkan sesuatu ke dalam tubuh.

Jarak kelahiran di bawah 18 bulan atau lebih dari 59 bulan berhubungan secara signifikan terhadap peningkatan risiko terjadinya keluaran perinatal yang kurang baik, seperti persalinan prematur, BBLR, dan IUGR. Jarak kelahiran yang dekat juga berhubungan dengan meningkatnya risiko terjadinya ketuban pecah dini, abruptio plasenta dan plasenta previa, serta kemungkinan terjadinya ruptur uteri pada wanita yang berusaha untuk melahirkan per vaginam setelah persalinan secara caesar sebelumnya. Sedangkan jarak kelahiran lebih dari lima tahun berhubungan dengan peningkatan risiko preklamsi (CondeAgudelo, 2012).

Berdasarkan tabel 1 dapat diketahui bahwa jarak kelahiran yang terjadi pada kematian maternal yang dapat dicegah di Kabupaten Garut berasal dari jarak kelahiran berisiko rendah, yaitu jarak kelahiran $\geq 2$ tahun, yaitu sebanyak 27 kasus dari keseluruhan kematian. Untuk jarak kelahiran, 13 dari 45 kasus tidak mempunyai data dikarenakan ibu melahirkan anak pertama (paritas satu) dan 1 kasus ibu belum pernah melahirkan (G2P0A2). Namun demikian, masih terdapat 4 kasus di mana jarak kelahiran $<2$ tahun. Keadaan ini menggambarkan bahwa program $\mathrm{KB}$ belum sepenuhnya berjalan dengan baik di Kabupaten Garut. Jika dilihat dari tingkat pendidikan dan sosial ekonomi yang menengah ke bawah serta sulitnya memotivasi masyarakat mengenai penggunaan alat kontrasepsi, maka penggunaan alat kontrasepsi post plasenta merupakan solusi tepat untuk menekan angka kelahiran yang tinggi di Kabupaten Garut. Kontrasepsi yang dapat digunakan pada pasca persalinan dan paling potensi untuk mencegah mis opportunity berKB adalah Alat Kontrasepsi dalam Rahim (AKDR) atau Intra Uterine Device (IUD) post plasental, yaitu pemasangan dalam 10 menit pertama sampai 48 jam setelah plasenta lahir.

KB IUD post plasenta sangat tepat jika diterapkan di Kabupaten Garut, melihat jumlah kelahiran tinggi dan masih banyak ibu dengan usia $>35$ tahun, paritas $\geq 4$ kali, serta jarak kelahiran di bawah 2 tahun serta di atas 5 tahun yang hamil dan melahirkan di sana.

Penggunaan IUD post plasental dikontraindikasikan pada ibu yang mengalami infeksi saat persalinan, perdarahan post partum, dan sepsis. Berdasarkan penelitian yang dilakukan di India (2016) dan berdasarkan rekomendasi dari American College of Obstetricians and Gynecologist (ACOG), IUD post plasental merupakan metode kontrasepsi unggulan, terutama di daerah dengan tingkat kesadaran terbatas dan akses mengenai perawatan postpartum dan keluarga berencana terbatas (Soni, 2016)

Berdasarkan tabel 1 dapat dilihat bahwa di Kabupaten Garut, rata-rata masyarakatnya berpendidikan Sekolah Dasar (SD) sebesar 51,1\%. Pendidikan yang rendah ini berdampak pada banyak hal, di antaranya pengetahuan yang rendah, khususnya di bidang kesehatan; tingginya pernikahan usia dini akibat putus sekolah/tidak melanjutkan sekolah.

Berdasarkan temuan kuantitatif yang digambarkan pada tabel 1, didapatkan bahwa sebagian besar kematian maternal yang dapat dicegah berasal dari ibu yang memeriksakan kehamilannya lebih dari empat kali. Hal ini bertolak belakang dengan literatur yang 
menyatakan semakin sering ibu memeriksakan kehamilannya, maka kemungkinan untuk terjadinya kematian maternal akan menjadi lebih rendah. Tetap terjadinya kematian dimungkinkan pada saat ANC, ibu tidak mendapatkan pelayanan antenatal yang berkualitas, meskipun dari segi frekuensi sudah sesuai standar WHO. Pelayanan antenatal berkualitas seharusnya memenuhi kriteria 10 T. Penapisan untuk segera merujuk ke PONED/RS mungkin juga belum dipahami dengan baik oleh para tenaga kesehatan atau kalaupun petugas kesehatan sudah akan merujuk pasien, pasien dan keluarganya menolak sehingga terlambat untuk mendapatkan pelayanan kesehatan yang mumpuni.

Beberapa hal yang sering kali sulit dilakukan oleh tenaga kesehatan dalam pemberian pelayanan adalah temu wicara/konseling terhadap ibu dan keluarganya, terutama tentang pengambilan keputusan saat kegawatdaruratan. Pengambilan keputusan biasanya dilakukan oleh suami, namun pada saat ibu melakukan kunjungan ANC, sering kali suami tidak mendampingi dengan alasan harus bekerja. Padahal pada saat kegawatdaruratan terjadi ibu tidak mungkin untuk berpikir jernih dalam mengambil keputusan karena mungkin saja pada saat itu ibu sedang mengalami kesakitan. Upaya yang mungkin bisa dilakukan adalah tenaga kesehatan mengadakan posyandu pada saat para suami tidak bekerja, misal pada hari Sabtu atau di hari di mana biasanya para suami sedang berada di rumah atau dengan melakukan jemput bola dengan mendatangi rumah-rumah yang dirasa perlu untuk mendapatkan kunjungan.

Keberadaan Posyandu juga perlu diaktifkan lagi, jangan hanya ada tempat, tapi tidak ada pelayanan yang diberikan. Seperti yang disampaikan oleh beberapa responden, Posyandu ada, tapi tidak ada pelayanan, hanya sebatas timbang, tensi, dan "diraba-raba."

SDM yang berganti, khususnya bidan pun menjadi kendala, di mana ada beberapa desa yang mengeluhkan kinerja bidan desa yang dirasa kurang mampu mengambil hati masyarakat sehingga motivasi masyarakat untuk memeriksakan kehamilannya menurun.

Dari temuan kuantitatif yang dicantumkan dalam tabel 1, diketahui kematian maternal yang dapat dicegah justru lebih banyak terjadi pada ibuibu yang tidak mempunyai penyakit penyerta. Hal ini bertolak belakang dari literatur yang menyatakan ibu dengan penyakit penyerta memiliki risiko yang lebih besar untuk terjadinya kematian. Dari data kuantitatif didapatkan bahwa ibu yang mempunyai penyakit penyerta, seperti jantung (4 dari 45 kematian), hamil lebih dari dua atau tiga kali. Ibu dengan riwayat penyakit jantung seharusnya tidak diperkenankan untuk hamil lagi karena dengan hamil dikhawatirkan akan memperberat penyakit jantungnya dan berakibat komplikasi yang pada akhirnya dapat menyebabkan kematian. Satu di antara empat kasus kematian tersebut bahkan si ibu sudah hamil delapan kali. Hal ini menunjukkan bahwa suami dan keluarga kurang aware terhadap kesehatan ibu.

Di Kabupaten Garut, di beberapa tempat masih mempercayai paraji sebagai penolong persalinan. Bahkan ada yang sudah hamil delapan kali dan sudah diinformasikan bahwa ibu harus bersalin pada petugas kesehatan namun pada akhirnya tetap memilih bersalin di paraji dan akhirnya meninggal karena plasenta tidak lahir satu setengah jam setelah persalinan. Setelah dikonfirmasi, jawaban yang diberikan adalah bahwa dulu-dulu juga melahirkan di paraji tidak ada masalah, sudah biasa, jadi ya yang ini pun tidak apa-apa. Meskipun paraji sudah bermitra dengan bidan, namun ada kalanya paraji yang digunakan berasal dari daerah lain, yang belum bermitra dengan bidan setempat. Kepercayaan terhadap paraji ini dikaitkan dengan beberapa sebab, di antaranya adalah jika dengan paraji ibu merasa lebih nyaman karena mungkin paraji bersifat kekeluargaan dan lebih ramah dibandingkan bidan setempat atau di rumah sakit, di mana ibu harus berada di ruangan yang asing sendirian dan menimbulkan ketakutan tersendiri bagi ibu; dari segi biaya, persalinan di paraji lebih terjangkau jika dibandingkan di bidan atau di rumah sakit. Jika bersalin di paraji hanya berkisar 100-300 ribu, sedangkan di bidan lebih dari 600 ribu bahkan lebih. Beberapa dari kasus kematian juga masih ada yang menganggap bahwa persalinan di bidan hanya untuk yang sulit-sulit saja, jadi bidan dipanggil apabila sudah mengalami komplikasi sehingga terkadang bidan terlambat untuk memberikan pertolongan.

Dari 45 kasus kematian maternal, 10 di antaranya disebabkan oleh eklampsia. Pada eklampsia ditemukan kejang-kejang, yang bagi sebagian orang awam merupakan kondisi di mana ibu dirasuki oleh roh halus/kesurupan. Ada beberapa kasus yang saat terjadi kejang, karena pengetahuan yang minim dan masih percaya dengan hal-hal yang berbau mistis, ibu tidak dibawa mencari pertolongan ke tenaga kesehatan, 
tapi justru dibawa ke "orang pintar" atau dukun. Salah satunya adalah kasus di mana seorang wanita berusia 18 tahun mengalami kejang pada periode kehamilan, namun dari keluarga menolak pengobatan karena ayahnya seorang dukun dan menganggap kejang yang dialami anaknya merupakan gangguan roh halus, sehingga akhirnya ibu meninggal di rumah tanpa mendapat pertolongan tenaga kesehatan.

\section{Faktor tenaga kesehatan}

Dari 45 kasus kematian maternal yang terjadi di Kabupaten Garut, lebih dari 50\% persalinan ditolong oleh tenaga kesehatan. Hal ini menunjukkan mulai tumbuhnya kesadaran dan pemahaman di masyarakat tentang arti bidan sebagai penolong persalinan yang bersih dan aman. Namun demikian masih terdapat juga yang bersalin dengan bantuan dukun beranak/paraji, yaitu 10 dari 45 kasus kematian. Masih ada masyarakat yang beranggapan bahwa jika melahirkan di bidan itu untuk persalinan yang susah, sedangkan yang mudah tidak apa-apa kalau melahirkan di rumah. Mereka yang memilih bersalin di dukun mempunyai persepsi bahwa jika melahirkan di fasilitas kesehatan justru akan membahayakan, berdasarkan pengalamanpengalaman tetangga atau kerabat yang mungkin pada saat dibawa ke fasilitas kesehatan malah meninggal. Padahal beberapa dari mereka yang bersalin pada paraji pernah kontak dengan bidan melalui kunjungan ANC. Hal ini menunjukkan kurangnya follow up atau mungkin komunikasi yang kurang baik antara bidan dan ibu beserta keluarganya sehingga ibu lebih memilih melahirkan di paraji.

Berkaitan dengan kompetensi penolong persalinan, berdasarkan data kualitatif, didapatkan bahwa belum semua bidan mengikuti pelatihan APN (Asuhan Persalinan Normal) dan PPGDON. Pelatihan ini penting karena dalam keadaan gawat darurat bidan harus bisa menentukan tindakan yang tepat untuk menyelamatkan nyawa ibu dan bayi.

\section{Faktor Sarana Prasarana}

Berdasarkan data kuantitatif, $71,1 \%$ kematian maternal terjadi di RSUD sebagai rumah sakit pusat rujukan di Kabupaten Garut. Faktor sarana prasarana berkontribusi terhadap 11,9\% kematian maternal yang dapat dicegah. Dari hasil kualitatif didapatkan bahwa sarana prasarana berkontribusi banyak terhadap kematian maternal, khususnya yang terjadi di rumah sakit. Ketidaktersediaan darah, tabung oksigen, keterbatasan bed di ruang $\mathrm{ICU}$, dan peralatan sectio saecarea (SC) maupun curretage yang terbatas menjadi kendala. Darah memegang peran utama dalam penyelamatan ibu yang mengalami perdarahan, khususnya perdarahan postpartum. Namun minimnya ketersediaan darah mengakibatkan nyawa ibu tidak tertolong di rumah sakit. Kurangnya komunikasi antara tenaga kesehatan dan keluarga juga menjadi penyebab terlambatnya keluarga mendapatkan darah, di mana berdasarkan kesaksian keluarga, pihak tenaga kesehatan (dokter) tidak memberitahu bahwa ibu membutuhkan transfusi darah.

Keterbatasan ruang ICU juga menjadi kendala, di mana RSUD yang ada sebagai tempat rujukan utama dengan jumlah persalinan lebih dari 3000 (untuk periode Januari-April 2016), sehingga terkadang pihak RS harus menolak pasien karena memang tidak tersedia tempat di RS. Saat ini pihak RSUD sedang mengembangkan ruang HCU sebagai alternatif ruang ICU, meskipun tidak seketat ICU, paling tidak pasien tetap mendapat observasi ketat persiapan sebelum atau sesudah operasi. Kadangkala pasien yang merupakan pasien rujukan sudah berada pada kondisi terminal, sehingga meskipun dilakukan upaya penyelamatan tidak akan efektif lagi.

Di Kabupaten Garut bagian selatan, terdapat RS yang rencananya akan diakuisisi oleh Pemprov Jawa Barat. Di Kabupaten Garut bagian selatan, RS ini merupakan satu-satunya pusat rujukan bagi warga di 16 kecamatan sekitar yang berjumlah \pm 507.089 jiwa. Namun demikian, sarana prasarana yang dimiliki oleh RS ini masih jauh dari ideal di mana RS ini hanya memiliki 47 tempat tidur dan baru ditambah 32 tempat tidur pada 2016 yang lalu. RS ini juga belum memiliki ruang operasi dan ICU, sehingga beberapa pasien yang memerlukan pengobatan khusus masih harus dirujuk ke RSUD. Selain itu, dari segi SDM, RS ini juga masih sangat kekurangan tenaga, dengan hanya adanya 3 dokter umum dan 4 dokter spesialis yang belum mampu menangani untuk jumlah kunjungan 150-200 pasien per harinya. Untuk itu diharapkan Pemprov Jabar dapat segera mengambil alih RS ini untuk dapat ditingkatkan menjadi RS tipe B sehingga dapat melayani kebutuhan masyarakat, khususnya di Kabupaten Garut bagian selatan, di bidang kesehatan secara optimal dan memperpendek jarak rujukan sehingga dapat menurunkan angka kematian akibat keterlambatan pelayanan. 


\section{Faktor Rujukan}

Faktor rujukan meliputi 3 Terlambat, wilayah tempat tinggal, letak geografis, jarak dan waktu tempuh, transportasi, serta pembiayaan.

1. Faktor Tiga Terlambat (3T)

a. Terlambat mengenali tanda bahaya dan pengambilan keputusan untuk mencari pertolongan

Tanda bahaya kehamilan, persalinan, maupun nifas hendaknya diketahui oleh ibu dan keluarga yang didapatkan dari buku KIA maupun informasi langsung dari tenaga kesehatan saat kunjungan ANC. Hendaknya ibu dan keluarga memahami bahwa semua kehamilan itu berisiko, karena meskipun pada awalnya tidak terdapat penyakit atau sesuatu yang membahayakan, dengan adanya kehamilan komplikasi yang tidak terprediksi bisa saja terjadi. Oleh karena itu dibutuhkan komunikasi yang baik antara ibu maupun keluarga dengan tenaga kesehatan pemberi layanan sehingga memudahkan ketika terjadi komplikasi atau keadaan yang tidak diinginkan.

Di Kabupaten Garut, rata-rata latar belakang pendidikan ibu maupun suami adalah $\mathrm{SD}$, sehingga terkadang sulit untuk mengenali tanda kegawatdaruratan yang terjadi pada ibu, baik pada saat hamil, bersalin, maupun nifas. Pengambilan keputusan masih terpusat pada suami, sehingga jika suami terlambat berpikir cepat dan tepat akan berdampak pada keselamatan ibu. Pada saat terjadi kegawatdaruratan ibu cenderung tidak bisa memutuskan karena mungkin sedang kesakitan, sehingga diperlukan pemberian edukasi terhadap suami dan keluarga mengenai tanda bahaya dan pengambilan keputusan yang cepat dan tepat. Cepat dan tepatnya respon keluarga dalam pengambilan keputusan juga dipengaruhi oleh pandangan keluarga mengenai keseriusan kondisi, ketersediaan biaya untuk merujuk dan biaya selama perawatan dan pandangan tentang kualitas pelayanan di fasilitas kesehatan. Selain dari pasien dan keluarga, pengambilan keputusan untuk merujuk pun harus dilakukan oleh tenaga kesehatan sesuai dengan wewenangnya. Tenaga kesehatan, khususnya bidan, harus mampu mengenali tanda-tanda Ada Potensi Gawat Obstetri (APGO), Ada Gawat Obstetri (AGO), dan Ada Gawat Darurat Obstetri (AGDO) sehingga rujukan dapat dilakukan tepat waktu sehingga diharapkan dapat menurunkan kasus kematian ibu akibat keterlambatan dalam melakukan rujukan.

b. Terlambat mencapai fasilitas kesehatan
Kondisi geografis di Kabupaten Garut sebagian besar merupakan dataran tinggi dengan wilayah berbukit-bukit dan pegunungan. Kondisi ini memengaruhi dalam akses menuju ke fasilitas kesehatan. Beberapa wilayah justru tidak bisa dilalui oleh kendaraan roda empat (mobil) sehingga mempersulit pada saat harus dilakukan rujukan. Beberapa kasus kematian maternal yang terjadi di Kabupaten Garut dilandasi oleh keterlambatan dalam mencari transportasi. Belum berjalannya Desa Siaga Aktif menjadi salah satu permasalahan, di mana berarti belum tersedianya transportasi desa untuk melakukan rujukan. Keterlambatan dalam mencari transportasi juga tidak lepas dari keterlambatan dalam pengambilan keputusan, yang biasanya dilandasi oleh faktor ketidaktersediaan biaya untuk transportasi.

c. Terlambat mendapatkan penanganan adekuat di fasilitas kesehatan

Keterlambatan dalam penanganan adekuat di fasilitas kesehatan terjadi pada beberapa kasus, di antaranya karena ketidaktersediaan darah dan bed di ruangan ICU yang terbatas, serta akibat sikap dan perilaku tenaga kesehatan yang kurang aware terhadap kondisi pasien.. Permasalahan ini sudah disampaikan ke manajemen rumah sakit, namun belum menemui titik terang karena pihak manajemen rumah sakit mempunyai prioritas tersendiri. Minimnya sarana prasarana di ruang operasi membuat penanganan terhadap pasien tidak bisa dilakukan secara cepat sehingga mungkin diperlukan pengembangan rumah sakit terutama dari segi sarana prasarana.

Keterlambatan penanganan di rumah sakit juga terkendala dari kondisi pasien pada saat tiba di rumah sakit. Ketika pasien, terutama yang merupakan pasien rujukan, sampai di rumah sakit dalam kondisi sudah parah, maka penanganan yang dilakukan di rumah sakit pun menjadi tidak efisien lagi.

2. Faktor Wilayah Tempat Tinggal

Dari hasil data kuantitatif didapatkan bahwa sebagian besar kematian maternal di Kabupaten Garut berasal dari wilayah perdesaan. Hasil ini sejalan dengan literarur yang menyatakan bahwa ibu yang tinggal di kota atau daerah pesisir, memiliki risiko yang lebih rendah dibandingkan dengan ibu yang tinggal di desa atau daerah pedalaman atau terpencil.(Ronsman, 2009 dan Liang, 2011)

Ibu yang tinggal di desa cenderung berpendidikan rendah dan menikah usia dini, di mana kedua faktor ini merupakan faktor risiko 
untuk terjadinya kematian. Di daerah pedesaan, akses menuju ke fasilitas kesehatan pun terbilang sulit, meskipun sudah ada bidan desa di masingmasing tempat, namun jika terjadi komplikasi, fasilitas kesehatan dengan sarana prasarana yang memadai sulit terjangkau.

\section{Faktor Letak Geografis}

Kematian maternal di Kabupaten Garut hampir seluruhnya terjadi di dataran tinggi. Hal ini dikarenakan karena memang sebagian besar wilayah Kabupaten Garut merupakan dataran tinggi dengan kondisi berbukit-bukit dan pegunungan. Kondisi geografis ini kerap menjadi masalah saat akan melakukan rujukan pada kondisi yang gawat darurat. Rumah-rumah yang terletak di perbukitan dan di kaki gunung berkaitan dengan akses menuju ke fasilitas kesehatan. Bahkan untuk menuju ke Polindes pun sulit karena rumah berada pada geografis yang untuk dilewati kendaraaan roda dua pun sulit. Jika musim penghujan tiba, kondisi akan semakin sulit di mana jalan-jalan tergenang air yang mengakibatkan jalan menjadi licin dan becek serta beberapa tempat merupakan daerah rawan longsor. Untuk membawa pasien menggunakan tandu sampai ke daerah yang bisa dilalui motor. Hal inilah yang terkadang menyebabkan keterlambatan mendapatkan penanganan kesehatan pada pasien. Ada baiknya dengan kondisi pemukiman yang seperti itu, pemerintah bekerjasama dengan warga setempat menyediakan "rumah singgah" bagi ibu, khususnya bagi ibu-ibu yang mempunyai faktor risiko tinggi terjadi komplikasi.

4. Faktor Akses (transportasi, waktu, dan jarak tempuh)

Jika dilihat dari jarak tempuh dari rumah ke fasilitas kesehatan terdekat, di Kabupaten Garut sebagian besar berjarak lebih dari lima kilometer. Namun jika dikaitkan dengan waktu tempuh, jarak tersebut dapat ditempuh dengan waktu kurang dari dua jam. Namun demikian, di beberapa tempat, jarak dan waktu tempuh menjadi masalah, di mana jarak $18 \mathrm{~km}$ harus ditempuh dalam waktu 120 menit. Hal ini berkaitan pula dengan letak geografis dan transportasi yang tersedia. Seperti di Desa Cisarua, Kecamatan Samarang, sebenarnya tidak terlalu jauh dari pusat kota. Namun dengan kondisi jalan yang sempit, berbatu-batu, belum sepenuhnya aspal, bahkan masih terdapat jalan setapak yang berlumpur, hal itu menyebabkan sulitnya membawa pasien secara cepat. Belum lagi tidak semua rumah dapat dilalui kendaraan roda dua, sehingga masih harus melanjutkan perjalanan dengan berjalan kaki yang tentunya menyebabkan keterlambatan dalam membawa pasien ke fasilitas kesehatan.

Beberapa dari kematian maternal yang dapat dicegah didasari karena keterlambatan dalam mencari transportasi. Keterlambatan mencari transportasi ini juga dipengaruhi oleh terlambat dalam mengenali tanda bahaya dan pengambilan keputusan untuk mencari pertolongan serta faktor biaya. Beberapa suami memikirkan biaya untuk membayar transportasi sehingga hal itu yang membuat lama dalam mengambil keputusan. Desa Siaga Aktif tidak berjalan sehingga transportasi masih menjadi kendala di Kabupaten Garut. Untuk angkutan umum juga terbatas, tidak sampai malam hari. Hanya sebatas jam 18.00 WIB, sehingga apabila kegawatan terjadi di malam hari dan keluarga tidak mempunyai kendaraan, akan menambah sulit untuk merujuk. Di beberapa desa ada kendaraan milik tetangga yang dapat digunakan, namun ada kalanya hubungan antar tetangga yang kurang baik menjadi kendala untuk meminjam kendaraan tersebut.

\section{Faktor Pembiayaan}

Berdasarkan data kuantitatif, faktor pembiayaan tidak menyebabkan kematian maternal yang dapat dicegah secara langsung, namun berhubungan dengan hambatan rujukan yang akhirnya menyebabkan kematian maternal yang dapat dicegah. Sebagian besar keterlambatan dalam merujuk disebabkan faktor biaya. Untuk pembiayaan kesehatan, belum semua warga memiliki BPJS ataupun KIS (Kartu Indonesia Sehat), padahal KIS ada yang ditujukan bagi warga miskin atau tidak mampu yang iurannya dibayar oleh pemerintah. Persyaratannya pun cukup mudah, yaitu: 1) KK dan KTP seluruh anggota keluarga; 2) Surat keterangan tidak mampu dari RT dan kelurahan; dan 3) Surat pengantar dari puskesmas. Kurangnya kesadaran dari warga ataupun mungkin kurangnya sosialisasi dan informasi mengenai hal ini menyebabkan banyak warga tidak mampu di Kabupaten Garut yang belum memiliki KIS ini. Ketidaktersediaan biaya memengaruhi pengambilan keputusan suami untuk merujuk istrinya ke fasilitas kesehatan. Ketakutan tidak bisa membayar biaya persalinan, ketakutan istrinya tidak mendapat penanganan yang baik di fasilitas kesehatan, ketakutan untuk biaya selama menjaga di rumah sakit, dan beberapa terpengaruh dari berita di media tentang permasalahan pasien BPJS yang mendapatkan perlakuan kurang baik di fasilitas kesehatan. Bahkan terkadang untuk 
sekadar membayar biaya ambulance yang berkisar 100-150 ribu pun butuh pemikiran dan diskusi panjang, sehingga pada saat ibu akan dibawa ke fasilitas kesehatan, ibu sudah dalam kondisi koma atau bahkan meninggal di perjalanan.

Tidak tersedianya tabulin (tabungan persalinan) dan tidak adanya dana bersalin yang dikoordinir dari desa juga menjadi salah satu permasalahan di beberapa desa. Dari hasil kualitatif didapatkan para kader desa sudah semangat untuk mengumpulkan dana dan sudah memberi masukan kepada kepala desa, namun aparat desa yang baru saja diganti dan kurangnya perhatian dari kepala desa mengenai kematian ibu di desa tersebut membuat hal ini sulit terlaksana.

Ketidaktersediaan pembiayaan untuk persalinan dan perawatan ini juga menyebabkan adanya "peminjaman" BPJS milik tetangga atau kerabat yang menyebabkan banyak data yang tidak sinkron antara rekam medis rumah sakit dengan data di OVM. Peminjaman BPJS ini disebabkan oleh kurangnya kesadaran warga terhadap kesehatan, di mana banyak warga beranggapan bahwa jika tidak sakit, tidak usah mengurus BPJS.

\section{Pencatatan dan Pelaporan}

Di Kabupaten Garut, berdasarkan data dari Dinas Kesehatan Kabupaten Garut, kasus kematian maternal terlapor dan tercatat seluruhnya. Berbeda dengan perinatal yang memang banyak sekali yang tidak terdapat dokumen/OVP nya, untuk dokumen OVM lengkap dan terisi semua meskipun di beberapa bagian masih ada yang tidak terisi sempurna. Untuk pelaporan dilakukan segera setelah terjadi kasus kematian melalui media sosial WhatsApp yang dibentuk oleh kerjasama antara Dinas Kesehatan Kabupaten Garut, Dokter Spesialis Obstetri Ginekologi, dan para bidan. Grup ini dibentuk untuk memudahkan konsultasi, baik untuk kasus-kasus kegawatdaruratan maupun untuk pelaporan kematian maternal. Namun demikian grup WhatsApp yang dibentuk hanya efektif untuk pelaporan tapi tidak untuk pencatatan. Jika kematian terjadi tengah malam, mungkin memang bisa langsung dilaporkan tapi tidak bisa untuk langsung dicatat di buku register kematian Dinas Kesehatan, sehingga masih diperlukan aplikasi/sistem yang dapat memudahkan pencatatan dan pelaporan karena dapat digunakan setiap saat setiap waktu.

Idealnya semua kematian maternal yang terjadi dilakukan Audit Maternal Perinatal (AMP). Namun di Kabupaten Garut, tidak semua kasus dilakukan AMP disebabkan oleh beberapa hal, di antaranya dana, waktu, dan tenaga. Beberapa kasus yang sama dikelompokkan untuk kemudian dipilih salah satu kasus untuk pembelajaran dengan harapan kasus serupa tidak terjadi lagi di kemudian hari.

Peneliti juga telah mengklarifikasi data kematian ke Disdukcapil namun ternyata di sana yang tercatat adalah kematian secara global, mulai dari anak-anak hingga dewasa, tidak diklasifikasikan berdasarkan usia maupun penyebab. Data yang ada di Disdukcapil hanya berupa angka, yang didapatkan dari masingmasing kecamatan.

Selain di Disdukcapil, peneliti juga berusaha mencari data ke RSUD. Dari 33 kematian yang terjadi di RSUD, hanya 10 yang ada bentuk fisik rekam mediknya. Penyimpanan pun belum berjalan dengan baik, di mana tidak ada penyimpanan khusus untuk kasus-kasus kematian di RS, sehingga dibutuhkan waktu lama untuk mencari dokumen tersebut. Alasan lain yang digunakan adalah bahwa beberapa data rusak akibat banjir yang memang menerpa Kabupaten Garut beberapa waktu lalu. Dari hasil kualitatif, ditemukan bahwa laporan kematian dari RSUD ke Dinas Kesehatan dilakukan segera melalui WA, namun bentuk fisik (OVM dan RMM) baru diserahkan per bulan. Idealnya RMM diserahkan ke Dinas Kesehatan dalam waktu 3 hari setelah kematian terjadi.

Pengisian OVM pun baru dapat dilaksanakan setelah tujuh hari kematian, mengingat kemungkinan keluarga masih dalam keadaan berduka.

Pengisian lembar OVM masih belum sempurna, masih terdapat beberapa bagian yang tidak diisi sesuai pedoman. Pelatihan pengisian OVM sudah pernah dilakukan, namun tidak semua bidan mendapatkannya, hanya pada bidan koordinator saja, sedangkan yang mengisi OVM terkadang adalah bidan desa yang mungkin kurang paham mengenai pengisiannya

\section{Simpulan}

Penyebab kematian maternal di Kabupaten Garut adalah penyebab yang dapat dicegah, yaitu sebesar 96\%, disebabkan oleh multifaktor, yang didominasi oleh faktor pasien dan faktor tenaga kesehatan. Faktor pasien disebabkan oleh karakteristik ibu yang berisiko serta adanya persepsi negatif terhadap fasilitas kesehatan, 
sedangkan faktor pasien lebih kepada kurangnya konseling yang efektif dan tingkat kepatuhan tenaga kesehatan terhadap kewenangan yang dimiliki dalam memberikan asuhan.

\section{Daftar Pustaka}

Agudelo AC. 2012. 'Effects of Birth Spacing on Maternal, Perinatal, Infant, and Child Health: A Systematic Review of Causal Mechanisms.' Studies in Family Planning;43(2):93-114.

Ansariadi, 2014. 'Epidemiologi Kematian Ibu di Sulawesi Selatan 2008-2013: Apa yang telah berubah?' Padang: Disajikan dalam Mukernas Ikatan Ahli Kesehatan Masyarakat Indonesia.

Badan Pusat Statistik. 2013. Survei Demografi dan Kesehatan Indonesia 2012. Jakarta.

Dinkes Provinsi Jawa Barat. 2014. Profil Kesehatan Provinsi Jawa Barat. Bandung: Dinkes Prov Jawa Barat

Jentoft S, Nielsen VO. 2014. 'Adjusting Maternal Mortality Data for International Comparisons: The Case of Vital Registration Systems' Statistics Norway Research Department;773.

Kemenkes RI. 2014. Profil Kesehatan Indonesia Tahun 2013. Jakarta: Kementerian Kesehatan.

Liang J, Dai L, Zhu J, Li X, Zeng W, Wang H, et al. 2011. 'Preventable Maternal Mortality: Geographic/Rural-Urban Differences and associated Factors from The PopulationBased Maternal Mortality Surveillance System in China. BMC Public Health;11(243): hal 1-9.

Lim J. 2016. "The "three delays" at the root of maternal mortality.' International Journal of Gynecology dan Obstetrics 128, hal 62 7.

McCaw-Binns, Mullings, Holder Y. 2014. Vital Registration and Under Reporting of Maternal Mortality in Jamaica. International Journal of Gynecology and Obstetrics. 128:62-7.

Merali HS, Lipsitz S, Hevelone N, Gawande AA, et al. 2014. "Audit-identified avoidable factors in maternal and perinatal deaths in low resource settings: a systematic review' BMC Pregnancy and Childbirth: 14(280)

Pacagnella RP, Cecatti JG, Osis MJ, et al. 2012. 'The role of delays in severe maternal morbidity and mortality: expanding the conceptual framework.' Reproductive Health Matters; 20(39) hal 155-163.

Practice.2016. 'Immediate Postpartum LongActing Reversible Contraception.' The American College of Obstetricians and Gynecologist: Women's Health Care Physicians.

Pusat Data dan Informasi Kesehatan (Pusdatin). 2013. Ringkasan Eksekutif Data dan Informasi Kesehatan Provinsi Jawa Barat. Jakarta: Kementerian Kesehatan.

Ronsmans C, Scott S, Qomariyah SN, Achadi E, Braunholtz A, Marshal T, et al. 2009. 'Professional Assistance During Birth and Maternal Mortality in Two Indonesian Districts. Bulletin World Health Organization;87: 416-23.

Soni M, Sharma V. 2016. 'Post-placental postpartum intrauterine contraceptive devices insertion: our scenario'. International Journal Reproduction, Contraception, Obstetrics and Gynecology; 5(3): 766-769

UNICEF Indonesia. 2012. Ringkasan Kajian Kesehatan Ibu dan Anak Jakarta: UNICEF

USAID.2016. Referral System Strenghtening 2016. EMAS, USAID.

WHO, 2015. Saving Mothers's Live. Geneva, Swiss: WHO 